\title{
Barriers to use of geospatial data for adaptation to climate change and variability: case studies in public health
}

\author{
Joan L. Aron \\ Science Communication Studies, Columbia, Maryland 21045, USA
}

\begin{abstract}
This paper presents two case studies of the barriers to the use of geospatial data in the context of public health adaptation to climate change and variability. The first case study is on the hazards of coastal zone development in the United States with the main emphasis on Hurricane Katrina. An important barrier to the use of geospatial data is that the legal system does not support restrictions on land use intended to protect the coastal zone. Economic interests to develop New Orleans and the Mississippi River, both over the long term and the short term, had the effect of increasing the impact of the hurricane. The second case study is epidemics of climate-sensitive diseases with the main emphasis on malaria in Africa. Limits to model accuracy may present a problem in using climate data for an early warning system, and some geographic locations are likely to be more suitable than others. Costs of the system, including the costs of errors, may also inhibit implementation. Deriving societal benefits from geospatial data requires an understanding of the particular decision contexts and organizational processes in which knowledge is developed and used. The data by themselves will not usually generate a societal response. Scientists working in applications should develop partnerships to address the use of geospatial data for societal benefit.
\end{abstract}

Keywords: climate change, climate variability, adaptation, public health.

\section{Introduction}

Barriers to societal use of scientific information emerged as a theme at the Inter-American Institute for Global Change Research (IAI) Training Institute on Climate and Health in the Americas held on November $7-18,2005$ at the University of the West Indies (UWI) in Kingston, Jamaica (Aron, 2006).

Hurricane Katrina had devastated New Orleans and a great swath along the U.S. Gulf Coast in late August in that year of a very active North Atlantic hurricane season. Katrina caused the deaths of an estimated 1,330 people, 80 percent of whom were in the New Orleans metropolitan area. The storm also damaged an estimated 96 billion dollars of property, far more than any previous natural or

Corresponding author:

Joan L. Aron

Science Communication Studies

Columbia, Maryland 21045, USA

E-mail: JoanAron@mmscnet.org man-made disaster (Office of the White House, 2006). How could the hurricane cause such great loss of life and property in the United States with so much scientific information about the hazards? Although Katrina is a particularly dramatic example, it is by no means unique in demonstrating a gap between scientific data and societal use.

The purpose of this paper is to discuss barriers to use of geospatial data for adaptation to climate change and variability with a focus on two case studies in public health. The ultimate objective is to encourage scientists to appreciate and study the particular decision contexts and organizational processes in which knowledge is developed and used (Pulwarty et al., 2004).

A brief overview of the concept of adaptation to climate change and variability for public health is necessary to set the stage. The case studies address hazards of coastal zone development in a highly developed country and epidemics of climate-sensitive diseases with a principal focus on the developing world. 
Public health adaptation to climate change and variability

Adaptation is a process to moderate, cope with and take advantage of the consequences of climate events (Ebi et al., 2005a). In the climate community, climate variability refers to change in the climate system on time scales that are seasonal to interannual and decadal while the term climate change is reserved for centuries, millennia and longer periods. Adaptation to short-term climate variability is important in its own right and serves as a starting point for reducing vulnerability to long-term climate change. Five generic objectives of adaptation to climate change and variability are as follows (NiangDiop and Bosch, 2005):

(i) increasing robustness of infrastructure designs and long-term investment;

(ii) increasing the flexibility of vulnerable managed systems;

(iii) enhancing the adaptability of vulnerable natural systems;

(iv) reversing trends that increase vulnerability; and

(v) improving societal awareness and preparedness.

Public health depends on climate. There is growing recognition that vulnerability to climate change and variability is a concern for a variety of healthrelated issues: infectious diseases, natural disasters, food and nutrition security, water resources, heat stress, air pollution and asthma as well as interactions with stratospheric ozone depletion (McCarthy et al., 2001). The long history of public health interventions provides valuable information for adaptation (Ebi et al., 2005b). Approaches to adaptation involve both established interventions, such as the control of mosquitoes that transmit disease, and new strategies, such as incorporating projections of climate change into infrastructure development.

\section{Hazards of coastal zone development}

The U.S. Congress finds a national interest in the effective management, beneficial use, protection, and development of the coastal zone in the Coastal
Zone Management Act of 1972 amended through the Coastal Zone Protection Act of 1996. This legislation encourages states to manage coastal development to "minimize the loss of life and property caused by improper development in flood-prone, storm surge, geological hazard, and erosion-prone areas and in areas likely to be affected by or likely to be vulnerable to sea level rise, land subsidence, and saltwater intrusion, and by the destruction of natural protective features, such as beaches, dunes, wetlands, and barrier islands" (U.S. Congress, 2004).

A key U.S. Supreme Court decision, however, limits the ability of states to manage the coastal zone (U.S. Supreme Court, 1992). In Lucas v. South Carolina Coast Council in 1992, the Court ruled against a 1988 South Carolina ban on permanent habitable structures that was intended to reduce erosion on barrier islands. The ban deprived Lucas of economically viable use of his property. The Court agreed that the ban amounted to a "taking" that called for "just compensation" under the Fifth and Fourteenth amendments to the U.S. Constitution. The principle that the rights of individual property owners to the economic value of coastal land take precedence over hazard management is an important barrier to the use of geospatial hazard information.

Long before the 1992 Supreme Court decision, alliances among business interests, the U.S. Congress and the U.S. Army Corps of Engineers have supported environmentally-damaging engineering projects with questionable economic benefits. "All modern presidents have tried to rein in the Corps, but Congress has jealously protected it" (Grunwald, 2006). This political support for economic development has limited the societal use of geospatial hazard information and a critical examination of Corps projects. The Corps is responsible for the floodwalls that were supposed to protect the City of New Orleans but failed during Hurricane Katrina in 2005. Economic interests in Louisiana supported the Mississippi River Gulf Outlet, an alternative shipping channel built by the Corps, 
which appears to have amplified the storm surge from Hurricane Katrina.

The destructive power of major storms does offer opportunities for building new infrastructure. During Hurricane Mitch in 1998, Belize suffered tremendous damage of coastal infrastructure. The project coordinator for Belize's assessment of climate change impacts under the Framework Convention on Climate Change wrote to the Ministry of Works about the projected increase in sea level (Niang-Diop and Bosch, 2005). The result was that the design for the new seawall took sea level rise into account and was built higher than originally planned.

It remains to be seen if the wake-up call by Hurricane Katrina changes the political dynamics of the U.S. Congress and the U.S. Army Corps of Engineers. Engineering over many decades protected cities from flooding all along the Mississippi River but reduced the silt for building marshes and swamps in coastal Louisiana, which help to buffer the region from hurricane impacts (Grunwald, 2006). New Orleans itself is sinking at an average rate of $6 \mathrm{~mm}$ per year but at a rate as high as $29 \mathrm{~mm}$ near the edge of its levees (Reaney, 2006). The National Oceanic and Atmospheric Administration has predicted an active hurricane season in 2006, a pattern likely to continue for several years because the development of North Atlantic hurricanes is in an active phase of a multi-decadal pattern (National Oceanic and Atmospheric Administration, 2006). Global warming may lead to more intense hurricanes (Emanuel, 2005; Pielke et al., 2005). Global sea level is projected to rise due to climate change (Houghton et al., 2001).

\section{Epidemics of climate-sensitive diseases}

The use of climate data in early warning systems for epidemics is attracting a great deal of attention. Technical advances in forecasting seasonal to interannual variability due to the $\mathrm{El}$ Niño/Southern Oscillation (ENSO) and other factors have generated interest in using climate forecasts to improve dis- ease control. Long-term climate change has the potential to alter the dynamics of disease transmission, such as shifting the geographic regions where a disease is endemic.

For an early warning system, it is critical to consider both prediction and response (Woodruff, 2005). Problems in either of these areas may present a barrier to the use of geospatial data. Mosquitoborne diseases are particularly amenable to this analysis and will be used to illustrate the issues. Changes in climate can have a major effect on the habitat of mosquitoes transmitting diseases, the development of infectious agents within mosquitoes, and the activities that bring people into contact with mosquitoes.

Model accuracy is an essential component of prediction. The level of accuracy must be clearly defined and related to objectives for disease control. One problem is that highly-detailed spatio-temporal predictions of disease may not be technically feasible. An additional complication is that model accuracy depends on the ecological setting. For mosquito-borne diseases, early warning systems may be more suitable in areas with strong inter-annual variation (Woodruff, 2005). Botswana is such a location. Skillful seasonal climate forecasts for rainfall have been successful in predicting malaria epidemics in Botswana, adding up to four months lead time (Thomson et al., 2006). It may be difficult, however, to extend those results to Kenya where both seasonal rainfall and seasonal temperature are major factors in determining the appearance of malaria epidemics (Odhiambo, 2006) and there is evidence of a significant warming trend at high altitudes (Pascual et al., 2006). For longer time scales, uncertainties about climate change predictions are serious impediments. A general understanding of the role of climate and seasonality in disease transmission is complicated by effects that operate at different spatial scales and multiple seasonal drivers working in concert as well as concomitant biological and social changes, such as the emergence of antimalarial drug resistance and the population pressure to create new human settlements in areas highly suitable for 
malaria transmission (Pascual and Dobson, 2005).

In some settings, simpler systems to assign potential for transmission may be useful even in the absence of detailed predictions. There is also a tradeoff between timeliness and specificity. In general, predictions at longer lead times are less specific and reliable (Woodruff, 2005). It is important to clearly define what is meant by a successful prediction when linked to an early warning system.

The establishment of an early warning system must consider the costs and benefits of responses. The costs of operating an early warning system may exceed the benefits for disease control. An analysis of costs should include estimates of false positive predictions (false alarms) and false negative predictions (an epidemic appears that is not in the forecast). An attempt to identify all true epidemics may result in many false alarms. Conversely, an attempt to reduce false alarms may miss epidemics. These errors can impede the effectiveness of an early warning system despite some individual years in which predictions prove to be highly accurate. The error rate has implications for the credibility of the message as well. Maintaining credibility is essential. If there are serious communication errors, it may be difficult to win back the public's trust despite highly accurate forecasts (Institute of Medicine and National Research Council, 2005).

It should be noted that the perception of costs and benefits may be altered by the development context. The implementation of climate services in subSaharan Africa serves as an example (International Research Institute for Climate and Society, 2006). Providing the infrastructure for climate services in sub-Saharan Africa is a huge undertaking. However, climate services have been proposed as a sound development strategy to aid sub-Saharan economies, which are especially sensitive to climatic fluctuations because of their agrarian structure.

The establishment of an early warning system must be linked to a response mechanism that is acceptable to stakeholders in the disease control decisions. For example, the public may be opposed to the spraying of insecticides on a large scale.
Decisions to expend funds for early stages of preparedness must have public support in order to succeed.

Finally, a successful disease control program may contain the seeds of its own demise. If cases of disease are prevented, then the benefits of disease control may not be obvious and the costs of a control program may appear to be excessive. Dengue has resurged as a public health problem in the Americas in recent decades (Gubler and Wilson, 2005). During the 1950s and 1960s, an eradication campaign targeting the mosquito species Stegomyia aegypti (formerly Aedes aegypti), which transmits dengue and yellow fever, eliminated epidemics of these diseases in the tropical Americas. This success led to complacency and redirection of resources to other public health problems. Increased urbanization and deteriorating health infrastructure permitted the expansion of populations of the mosquito $S$. aegypti. International movements of people aided the spread of dengue viruses.

\section{Conclusion}

Geospatial data can be very useful in the context of public health adaptation to climate change and variability but there are barriers to translating scientific results into policies. The case study on coastal zone development in the United States highlighted the Supreme Court decision that does not support restrictions on land use intended to protect the coastal zone. The case study on epidemics of climate-sensitive diseases in Africa emphasized how costs of an early warning system, including the costs of errors, may exceed the benefits although the perception of costs and benefits may be altered by plans for economic development. Deriving societal benefits from geospatial data requires an understanding of the particular decision contexts and organizational processes in which knowledge is developed and used. Scientists are therefore urged to develop partnerships to address the use of geospatial data for societal benefit. 


\section{Acknowledgments}

I thank Roger Pulwarty for material about the barriers to the use of climate information. I also thank an anonymous reviewer for helpful comments.

\section{References}

Aron JL, 2006. IAI Training Institute on Climate and Health in the Americas: outreach from the IAI collaborative research network on climate variability and human health impacts in the tropical Americas. Adv Glob Change Res, in press.

Ebi KL, Lim B, Aguilar Y, 2005a. Scoping and designing an adaptation project. In: Lim B, Spanger-Siegfried E, eds. Adaptation Policy Frameworks for Climate Change: Developing Strategies, Policies and Measures. United Nations Development Program, Cambridge University Press, Cambridge UK, Technical Paper 1.

Ebi KL, Smith JB, Burton I, Hitz S, 2005b. Adaptation to climate variability and change from a public health perspective. In: Ebi KL, Smith JB, Burton I, eds. Integration of Public Health with Adaptation to Climate Change: Lessons Learned and New Directions, Taylor \& Francis, London, UK, Chapter 1.

Emanuel K, 2005. Increasing destructiveness of tropical cyclones over the past 30 years. Nature 436, 686-688.

Grunwald M, 2006. A flood of bad projects. The Washington Post (May 14, 2006), pp. B1, B5.

Gubler DJ, Wilson ML, 2005. The global resurgence of vector-borne diseases: lessons learned from successful and failed adaptation. In: Ebi KL, Smith JB, Burton I, eds. Integration of Public Health with Adaptation to Climate Change: Lessons Learned and New Directions, Taylor \& Francis, London, UK, Chapter 3.

Houghton JT, Ding Y, Griggs DJ et al., eds. 2001. Climate Change 2001: The Scientific Basis. Intergovernmental Panel on Climate Change, Cambridge University Press, Cambridge, UK.

Institute of Medicine and National Research Council, 2005. Public Health Risks of Disasters: Communication, Infrastructure and Preparedness. National Academies Press, Washington, DC.
McCarthy JJ, Canziani OF, Leary NA, Dokken DJ, White KS eds., 2001. Climate Change 2001: Impacts, Adaptation, and Vulnerability. Intergovernmental Panel on Climate Change, Cambridge University Press, Cambridge, UK.

National Oceanic and Atmospheric Administration, 2006. NOAA predicts very active 2006 North Atlantic hurricane season (May 22, 2006). http://www.publicaffairs.noaa.gov/ releases2006/may06/noaa06-056.html (accessed: May 2006).

Niang-Diop I, Bosch H, 2005. Formulating an adaptation strategy. In: Lim B, Spanger-Siegfried E, eds. Adaptation Policy Frameworks for Climate Change: Developing Strategies, Policies and Measures. United Nations Development Program, Cambridge University Press, Cambridge UK, Technical Paper 8.

Odhiambo Z, 2006. Watching weather could predict malaria epidemics. SciDev Net. http://www.scidev.net/News/ index.cfm? fuseaction=readNews\&itemid=2633\&language $=1$ (accessed: May 2006).

Office of the White House, 2006. The Federal Response to Hurricane Katrina - Lessons Learned. Washington, DC. http://www.whitehouse.gov/reports/katrina-lessonslearned (accessed: May 2006).

Pascual M, Ahumada JA, Chaves LF, Rodo X, Bouma M, 2006. Malaria resurgence in the East African highlands: Temperature trends revisited. Proc Nat Acad Sci USA 103, 5829-5834.

Pascual M, Dobson A, 2005. Seasonal patterns of infectious diseases. PLoS Medicine 2, e2-e5.

Pielke Jr RA, Landsea C, Mayfield M, Laver J, Pasch R, 2005. Hurricanes and global warming. Bull Amer Meteorol Assoc 86, 1571-1575.

Pulwarty RS, Broad K, Finan T, 2004. El Niño events, forecasts and decision-making. In: Bankoff G, Frerks G, Hilhorst D, eds. Mapping Vulnerability: Disasters, Development and People, Earthscan, London, UK, Chapter 6. Reaney P, 2006. New Orleans had major subsidence before Katrina. Reuters News Service (June 1, 2006) http://www.planetark.org/dailynewsstory.cfm/newsid/3659 6/story.htm

Thomson MC, Doblas-Reyes FJ, Mason sJ, Hagedorn R, Connor SJ, Phindela T, Morse AP, Palmer TN, 2006. Malaria early warnings based on seasonal climate forecasts from multi-model ensembles. Nature 439, 576-579.

U.S. Congress, 2004. Coastal Zone Management Act of 1972. Office of Ocean and Coastal Resource Management, 
National Ocean Service, National Oceanic and Atmospheric Administration. http://coastalmanagement. noaa.gov/czm/czm_act.html

U.S. Supreme Court, 1992. Lucas v. South Carolina Coast Council. 505 U.S. 1003 (1992). Abstract. Oyez Multimedia Resource. http://www.oyez.org/oyez/resource/case/215/

International Research Institute for Climate and Society, 2006. A Gap Analysis for the Implementation of the Global Climate Observing System Programme in Africa.
IRI Technical Report Number IRI-TR/06/1, International Research Institute for Climate and Society, Palisades, New York. http://iri.columbia.edu/outreach/publication/ report/06-01.

Woodruff RE, 2005. Epidemic early warning systems: Ross River virus disease in Australia. In: Ebi KL, Smith JB, Burton I, eds. Integration of Public Health with Adaptation to Climate Change: Lessons Learned and New Directions, Taylor \& Francis, London, UK, Chapter 6. 